\title{
Evaluating Methane Oxidation Efficiencies in Experimental Landfill Biocovers by Mass Balance and Carbon Stable Isotopes
}

\author{
Marlon A. Capanema and Alexandre R. Cabral*
}

Department of Civil Engineering, Faculty of Engineering, Université de Sherbrooke, 2500 boul. de l'Université, Sherbrooke, QC, Canada, J1K 2Rl.

*Corresponding author: E-mail: Alexandre.Cabral@Usherbrooke.ca; Phone: +1(819) 821-7906; Fax: +1(819) 821-7974.

\begin{abstract}
Biocovers are an alternative for mitigating fugitive and residual emissions of methane from landfills. In this study, we evaluated the performance of two experimental passive methane oxidation biocovers (PMOBs) constructed within the existing final cover of the St-Nicéphore landfill (Quebec, Canada). The biocovers were fed in a controlled manner with raw biogas and surface fluxes were obtained using static chambers. This enabled calculating mass balances of $\mathrm{CH}_{4}$ and oxidation efficiencies $\left(f_{o_{-} M B}\right)$. Most of the time, $f_{O_{-} M B} \geq 92 \%$ were obtained for loadings as high as $818 \mathrm{~g} \mathrm{CH}_{4} \mathrm{~m}^{-2} \mathrm{~d}^{-1}$ (PMOB-2) and $290 \mathrm{~g} \mathrm{CH}_{4} \mathrm{~m}^{-2} \mathrm{~d}^{-1}$ (PMOB-3B). The lowest efficiencies ( $f_{o_{-} M B}=45.5 \%$ and $34.0 \%$, respectively) were obtained during cold days (air temperature $\sim 0^{\circ} \mathrm{C}$ ). Efficiencies were also calculated using stable isotopes $\left(f_{o_{-}} S I\right)$; the highest $f_{o_{-} S I}$ were $66.4 \%$ for PMOB-2 and $87.3 \%$ for PMOB$3 \mathrm{~B}$; whereas the lowest were $18.8 \%$ and $23.1 \%$, respectively. However, $f_{o_{-} S I}$ values reflect $\mathrm{CH}_{4}$ oxidation up to a depth of $0.10 \mathrm{~m}$, which may partly explain the difference in regards to mass balance-derived efficiencies. Indeed, it is expected that a significant fraction of the total $\mathrm{CH}_{4}$ oxidation occurs within the zone near the surface, where there is greater $\mathrm{O}_{2}$ availability. The influence of the values of fractionation factors $\alpha_{\mathrm{ox}}$ and $\alpha_{\text {trans }}$ were also evaluated in this paper.
\end{abstract}

Keywords: Methane oxidation; biocover; mass balance; stable isotopes; fractionation factors

Capanema, M.A. and Cabral, A.R. (2012). Evaluating Methane Oxidation Efficiencies in Experimental Landfill Biocovers by Mass Balance and Carbon Stable Isotopes. Water Air and Soil Pollution, 223 (9): 5623-5635 


\section{Introduction}

Methane $\left(\mathrm{CH}_{4}\right)$ generated by the anaerobic decomposition of wastes in landfills is the second most important greenhouse gas (GHG) after carbon dioxide $\left(\mathrm{CO}_{2}\right)$ (Spokas et al., 2006); and its global warming potential is 25 times that of $\mathrm{CO}_{2}$ (IPCC, 2007). Furthermore, $\mathrm{CH}_{4}$ is one of the targeted gases included in the Kyoto mechanisms for mitigation of GHG emissions. Globally, it is estimated that $\mathrm{CH}_{4}$ emissions from landfills vary from 500 to $800 \mathrm{Tg} \mathrm{CH}_{4} \mathrm{yr}^{-1}$ (IPCC, 2007), which means 3 to $10 \%$ of overall (i.e. natural and human-related) $\mathrm{CH}_{4}$ emissions (Bogner and Matthews, 2003; Chanton et al., 2008a; De Visscher et al., 2004; Stern et al., 2007). In 2009, U.S. landfills were responsible for emitting $117.5 \mathrm{Tg}$ of $\mathrm{CH}_{4}$, which means $17 \%$ of total human-related $\mathrm{CH}_{4}$ emissions (USEPA, 2011). To prevent biogas from being emitted directly into the atmosphere, landfill gas recovery systems and landfill covers (daily and final) are required. However, no system is $100 \%$ efficient ( 85 to $90 \%$ according to Spokas et al., (2006)); therefore part of the generated biogas escapes to the atmosphere as fugitive emissions. Surface emissions of $\mathrm{CH}_{4}$ are variable in space and time and their values range from 0.0002 to $4000 \mathrm{~g} \mathrm{CH}_{4} \mathrm{~m}^{-2} \mathrm{~d}^{-1}$ (De Visscher et al., 1999). Chanton et al. (2009) found values ranging from 52-102 $\mathrm{g} \mathrm{CH}_{4}$ $\mathrm{m}^{-2} \mathrm{~d}^{-1}$ for 42 measurements within the U.S., while Abichou et al. (2011) reported several measurements taken in 11 sites across the U.S., with methane fluxes varying from 0.1 to $175.7 \mathrm{~g} \mathrm{CH}_{4} \mathrm{~m}^{-2} \mathrm{~d}^{-1}$. In addition, according to personal communication with Terry Johnson (Waste Management Inc.), the calculated average methane loading applied to cover systems in several Waste Management landfills with gas collection systems in the U.S. and Canada is approximately $28 \mathrm{~g} \mathrm{CH}_{4} \mathrm{~m}^{-2} \mathrm{~d}^{-1}$.

Management practices that could mitigate emissions of $\mathrm{CH}_{4}$ in landfills are of considerable importance in connection with environmental protection and sustainable development benefits. One promising alternative is to engineer the final cover so that it becomes a passive methane oxidation biocover (PMOB) (Cabral et al., 2010b; IPCC, 2007). The PMOB is a medium where $\mathrm{CH}_{4}$ is transformed into $\mathrm{CO}_{2}$, water and biomass by methanotrophic bacteria when it migrates to the atmosphere through the substrate of the biocover (Gebert and Groengroeft, 2006; Hilger and Humer, 2003; Humer and Lechner, 2001; Stern et al., 2007). Methanotrophic bacteria are heterotrophic and aerobic microorganisms that are ubiquitous in the environment. Methanotrophics of Type I (e.g. Methylobacter, Methylocaldum and Methylomonas gene) and Type II (e.g. Methylosinus and Methylocystis gene) are responsible for $\mathrm{CH}_{4}$ oxidation and can be identified in biocovers (Gebert, 2009; Jugnia et al., 2009). Several materials can be used for the PMOB substrate, for example organic materials such as compost, sewage sludge, peat, soil or a mixture of them (Hilger and Humer, 2003; Humer and Lechner, 2001; Iranpour et al., 2005). Inorganic materials such as sand, gravel, glass and foam can also be added in the substrate to reduce pressure drop and preferential pathways of gas within the biocover.

The process of microbial oxidation of $\mathrm{CH}_{4}$ is influenced by several factors, including, among others: temperature, moisture content, degree of water saturation $\left(S_{r}\right)$, organic matter content and the presence of vegetation on the surface. Methanotrophic bacteria are mesophiles and the optimal range of temperature for $\mathrm{CH}_{4}$ oxidation is from 25 to $30^{\circ} \mathrm{C}$ (Chanton and Liptay, 2000; Stern et al., 2007). It was reported that the highest methane oxidation could be reached in composts (or similar substrates) with moisture contents varying from $40 \%$ to $80 \%$ of the maximum water holding capacity (Humer and Lechner, 1999). Methane oxidation can also be 
affected when $S_{r}$ approaches $85 \%$; in this case, air becomes occluded in the substrate (Burnotte et al., 2005), with a subsequent drastic decrease in gas flow (Cabral et al., 2004). Furthermore, when $S_{r}$ is below 13\%, methanotrophic bacteria become inactive (Humer and Lechner, 1999). The organic matter content indicates the presence of nutrients for microbial maintenance and growth (Iranpour et al., 2005). High $\mathrm{CH}_{4}$ oxidation efficiencies (e.g. 90 to $100 \%$ ) were obtained in biocovers whose substrate was rich in organic matter, whereas low efficiencies (16\%) were registered in poor organic matter substrates (Chanton et al., 1999; Huber-Humer and Lechner, 2003). It has been shown that vegetation can increase the substrate porosity by the formation of secondary macro-pores in the spreading roots zone (i.e. rhizosphere) and thus increase atmospheric $\mathrm{O}_{2}$ penetration in the soil (Bohn et al., 2011; Nagendran et al., 2006). In addition, vegetation can increase the evapotranspiration of water generated by the oxidation of $\mathrm{CH}_{4}$ and water from precipitations (Huber-Humer and Lechner, 2003; Nagendran et al., 2006).

In the present study, we evaluated the potential of two passive methane oxidation biocovers with different configuration and substrates for oxidizing $\mathrm{CH}_{4}$ in actual field conditions at the St-Nicéphore landfill in Quebec, Canada, during the 2008 and 2009 monitoring campaign. Methane oxidation efficiencies $\left(f_{o}\right)$ and oxidation rates $\left(J_{o x}\right)$ were evaluated via the mass balance method using $\mathrm{CH}_{4}$ loading and $\mathrm{CH}_{4}$ outflux data. In addition, oxidation efficiencies were measured at several depths within the PMOBs via the carbon stable isotopes method. For clarity, the configuration characteristics of the two PMOBs and the respective instrumentation are presented.

Finally, a comparison of the two methods of evaluating $\mathrm{CH}_{4}$ oxidation is presented using mass balance results $\left(f_{o_{-} M B}\right.$ values at the surface) and stable isotopes data $\left(f_{o_{-} S I}\right.$ values at a depth of $\left.0.10 \mathrm{~m}\right)$.

\section{Materials and Methods}

\section{Experimental biocovers}

The passive methane oxidation biocovers were constructed in the middle of a capped area (silty clay cover) of the St-Nicéphore landfill, with the goal of monitoring the microbial $\mathrm{CH}_{4}$ abatement under actual field conditions. The configurations of PMOB-2 and PMOB-3B are shown in Figure 1. The two PMOBs under study measured $2.75 \mathrm{~m}(\mathrm{~W}) \times 9.75 \mathrm{~m}(\mathrm{~L})$ with a slope of $3.5 \%$. A drainage system was installed at the lowest point of each one to evacuate infiltrating waters. As shown in Figure 1, each PMOB was insulated from the outside environment by a 1.5-mm HDPE geomembrane (impermeabilization), and 0.15-m polystyrene panels (to prevent lateral migration of moisture due to temperature gradients). The substrate in PMOB-2 consisted of a mixture of 5 volumes of compost (before sieving through a 12-mm industrial sieve) and 1 volume of coarse sand, with a resulting organic matter content equal to $20 \% \mathrm{go.m} / \mathrm{g}_{\text {dry soil }}$, relative density $\left(\mathrm{G}_{\mathrm{s}}\right)$ of $2.24 \mathrm{~g} / \mathrm{cm}^{3}$ and total porosity equal to $64 \%$. The substrate of PMOB-3B consisted of a mixture of one volume of the same substrate used in PMOB-2 and one volume of 6.4-mm clean gravel, resulting in a coarser-medium, thereby improving atmospheric air penetration. The resulting organic matter content was equal to $6 \% \mathrm{~g}_{\mathrm{o} . \mathrm{m}} / \mathrm{g}_{\mathrm{dry}}$ soil, the relative density was $2.74 \mathrm{~g} / \mathrm{cm}^{3}$ and the total porosity was equal to $48 \%$. 
Both PMOB-2 and -3B were fed with raw biogas from a well (Figure 1). The amount of biogas fed into the system was controlled by means of a valve, and the flow could be monitored using mass flow meters (Sage Metering, Model SID-050-DC-24-DIG-GAS for PMOB-2 and SIG-0515-DC-24-DIG-RG2 for PMOB-3B) connected to a data acquisition system (SP-4000, Veritek). Each biocover was divided into four sections (profiles) along its main axis. In each, temperature (TMC20-HD; coupled HOBO U12 dataloggers; from Onset), water content ( $\mathrm{ECH}_{2} \mathrm{O}$ EC-5; connected to Em50 loggers; from Decagon), suction (not discussed herein) and gas concentrations (stainless steel gas probes with an inner diameter of $10 \mathrm{~mm}$ and capped at the top end with a rubber septum) were monitored at several depths (e.g. 0.05 to $0.80 \mathrm{~m}$, Figure 1) (Cabral et al., 2010b). Weather information such as atmospheric temperature was recorded continuously by a weather station (Ventage Pro 2 , Davis) installed approximately $10 \mathrm{~m}$ from the experimental biocovers.

\section{Surface flux of $\mathrm{CH}_{4}$ and gas analyses}

$\mathrm{CH}_{4}$ outfluxes were measured by the static chamber method at different spots along the main axis of the biocovers. $\mathrm{CH}_{4}$ concentrations were monitored within a Plexiglas ${ }^{\circledR}$ chamber (Odoflux, Odotech Inc.) using a portable flame ionization detector (TVA-1000B, Thermo Scientific) equipped with a data acquisition system. The chamber procedure and calculation methodology of surface fluxes are detailed in Roncato and Cabral (2012). $\mathrm{CH}_{4}, \mathrm{CO}_{2}$ and $\mathrm{O}_{2}$ concentrations of the raw biogas (from the biogas well) and of gas samples (from stainless steel gas probes installed at several depths within PMOBs) were measured in situ using a portable gas meter (Columbus Instruments Inc.) equipped with infrared sensors able to detect $\mathrm{CO}_{2}$ and $\mathrm{CH}_{4}$ on a scale from 0 100 vol. $\%$ and an electrochemical sensor calibrated to detect $\mathrm{O}_{2}$ from $0-21$ vol. $\%$.

\section{Methane oxidation efficiencies by mass balance and stable isotopes}

The mass balance method is based on $\mathrm{CH}_{4}$ loading and $\mathrm{CH}_{4}$ outfluxes in PMOBs. The percentage of methane oxidized is calculated according to equation 1 (Powelson et al., 2006):

$$
f_{o_{-} M B}=\left(1-\frac{J_{\text {outflux }}}{J_{\text {loading }}}\right) \times 100
$$

where $f_{O_{-} M B}=$ fraction of $\mathrm{CH}_{4}$ oxidized $\left(\mathrm{CH}_{4}\right.$ oxidation efficiency, \%); $J_{\text {outflux }}=$ emitted $\mathrm{CH}_{4}$ and $J_{\text {loading }}=$ loading $\mathrm{CH}_{4}$, both in $\mathrm{g} \mathrm{CH}_{4} \mathrm{~m}^{-2} \mathrm{~d}^{-1}$. The $\mathrm{CH}_{4}$ loadings were controlled by one mass flow meter per PMOB.

Recently, the carbon stable isotopes method has been largely employed by several authors in field studies (Abichou et al., 2006; Cabral et al., 2010b; Chanton et al., 2011; Chanton et al., 1999; De Visscher et al., 2004; Liptay et al., 1998; Stern et al., 2007). This approach is based on changes in the ratio of ${ }^{12} \mathrm{C}$ and ${ }^{13} \mathrm{C}$ isotopes as 
$\mathrm{CH}_{4}$ migrates through the biocover. It has been shown that methanotrophic bacteria preferentially consume the lighter and more abundant isotope $\left({ }^{12} \mathrm{C}\right)$, which causes changes in the isotopic composition of the residual gas that becomes enriched in ${ }^{13} \mathrm{C}$ (Chanton and Liptay, 2000; De Visscher et al., 2004). Indeed, the $\delta^{13} \mathrm{C}$ values of $\mathrm{CH}_{4}$ (that represent the carbon isotopic composition) from raw biogas are typically between -50 and $-61 \%$, whereas $\delta^{13} \mathrm{C}$ values of emitted $\mathrm{CH}_{4}$ are generally between -30 and $-50 \%$ (Chanton et al., 1999). The fraction of $\mathrm{CH}_{4}$ oxidized $\left(f_{o \_}\right.$SI $)$is calculated using $\delta^{13} \mathrm{C}$ values and the equation 2 (Abichou et al., 2006):

$$
f_{o_{-} S I}=0.1 \times \frac{\delta_{E}-\delta_{A}}{\alpha_{o x}-\alpha_{\text {trans }}}
$$

where $\delta_{\mathrm{A}}=\delta^{13} \mathrm{C}$ value of anoxic zone (raw biogas); $\delta_{\mathrm{E}}=\delta^{13} \mathrm{C}$ value of emitted $\mathrm{CH}_{4} ; \alpha_{\mathrm{ox}}=$ isotopic fractionation factor for bacterial oxidation and $\alpha_{\text {trans }}=$ isotopic fractionation factor associated with gas transport in the biocover (Abichou et al., 2006).

In this study, $35-\mathrm{ml}$ gas samples were taken from stainless steel gas probes installed at several depths within the PMOBs, transferred to evacuated glass vials sealed with rubber stoppers and then stored at $4{ }^{\circ} \mathrm{C}$ until isotopic analyses. Samples taken inside flux chambers (i.e. at the surface) were quite diluted (volumetric concentrations of $\mathrm{CH}_{4}$ usually below $0.05 \%$ ) and with the methodology adopted and the equipment available, it was not possible to obtain reliable isotopic compositions $\left(\delta^{13} \mathrm{C}\right.$ values) for them. In addition, Cabral et al. (2010b) observed a recurring loss of enrichment near the surface $\left(\delta^{13} \mathrm{C}\right.$ becomes more negative as the gas moves up the profile; see discussion below). Due to the preceding, it was decided not to send surface samples for isotopic analyses.

In 2008, isotopic analyses (i.e. measures of the $\delta^{13} \mathrm{C}$ values) were carried out at the Delta-Lab (Geological Survey of Canada, GSC-Quebec) by gas chromatography-combustion-isotope ratio mass spectrometry (GC-CIRMS). The GC-C-IRMS system consists of a HP 5890 Series II gas chromatograph coupled with a VG Prism III isotopic ratio mass spectrometer via a combustion interface VG Isochrom II. The GC column was a PoraPlot Q (Varian, CP-7551) plot-fused silica column $(25 \mathrm{~m}, 0.32 \mathrm{~mm})$. The results obtained were normalized (recalculated versus the reference standard Vienna Peedee Belemnite - VPDB) using three internal gas standards whose precision and accuracy were $\pm 0.4 \%$. Two of the standards (BISO- 1 and HISO- 1 ) were mixtures of $0.25 \%$ methane and air. These were calibrated versus VPDB at the University of Victoria, BC. The third gas, $\mathrm{CO}_{2}$ had a $\delta^{13} \mathrm{C}$ value different from the reference gas. The latter was obtained from the BOC and calibrated versus VPDB at Delta-Lab.

In 2009, the $\delta^{13} \mathrm{C}$ values were measured at G.G. Hatch Lab (University of Ottawa). The GC-C-IRMS system consists of a HP 5890 Series II gas chromatograph coupled with a Delta Plus (Thermo-Finnigan) isotopic ratio mass spectrometer via a combustion interface GC combustion III. The GC column was a PoraPlot Q (Varian, CP-7551) plot-fused silica column $(25 \mathrm{~m}, 0.32 \mathrm{~mm})$. The results obtained were normalized using two internal gas standards (NSG1-RM8559, ${ }^{13} \mathrm{C}=-29.11$ and NSG2-RM8560, ${ }^{13} \mathrm{C}=-44.84$ ) whose precision and accuracy were $0.2 \%$. 
The isotopic fractionation factor for bacterial oxidation $\left(\alpha_{\mathrm{ox}}\right)$ from Eq. 2 measures the bacteria's preference for the ${ }^{12} \mathrm{C}$ isotope over the ${ }^{13} \mathrm{C}$ isotope and can be empirically determined by a closed system incubation test (Liptay et al., 1998). In this study, the test was carried out using the mixture sand-compost from PMOB-2 taken within the $30-\mathrm{cm}$ layer below the surface. $10 \mathrm{~g}$ of soil were incubated in a $100-\mathrm{ml}$ glass vial at $20^{\circ} \mathrm{C}$. Then, a volume of $90 \mathrm{ml}$ of $\mathrm{CH}_{4}$ was added in the vial so that the initial concentration of $\mathrm{CH}_{4}$ was $15 \%$. A total of 10 vials were prepared in duplicate. $\mathrm{CH}_{4}$ concentrations were measured over a 32-hour period using a gas chromatograph (Micro GC 3000A, Agilent Technologies) coupled with a thermal conductivity detector (TCD) to determine the rate of $\mathrm{CH}_{4}$ consumption by methanotrophic bacteria. Simultaneously to the $\mathrm{CH}_{4}$ concentration analyses, samples of $30 \mathrm{ml}$ of gas were taken and stored at $4^{\circ} \mathrm{C}$ until stable isotope analyses. The $\alpha_{o x}$ value was calculated using the Rayleigh equation (De Visscher et al., 2004; Liptay et al., 1998):

$$
\alpha_{o x}=\frac{\ln \left(\delta^{13} C_{0}+1000\right)-\ln \left(\delta^{13} C_{t}+1000\right)}{\ln \left(C H_{4, t} / C H_{4,0}\right)}+1
$$

where $\delta^{13} \mathrm{C}_{0}=\delta^{13} \mathrm{C}$ value at the beginning of the incubation test; $\delta^{13} \mathrm{C}_{\mathrm{t}}=\delta^{13} \mathrm{C}$ value at the end of the test when the decreasing concentration of $\mathrm{CH}_{4}$ starts to stabilize; $\mathrm{CH}_{4,0}=$ initial concentration of $\mathrm{CH}_{4}(15 \%)$; $\mathrm{CH}_{4, \mathrm{t}}=$ final concentration of $\mathrm{CH}_{4}$.

For the purpose of calculating oxidation efficiencies $\left(f_{o \_} S I\right), \alpha_{\mathrm{ox}}$ had to be corrected to the actual soil temperature measured at the respective depth, according to the temperature dependence suggested by Chanton et al. (2008b) (i.e. $0.00039^{\circ} \mathrm{C}^{-1}$ ) and equation 4 , where corr. $\alpha_{\mathrm{ox}}$ is the corrected $\alpha_{\mathrm{ox}}$ and $\mathrm{T}$ is the actual soil temperature.

$$
\text { corr. } \alpha_{o x}=\alpha_{o x}+0.00039\left(20-T\left({ }^{\circ} \mathrm{C}\right)\right)(4)
$$

The isotopic fractionation factor associated with gas transport in the biocover ( $\left.\alpha_{\text {trans }}\right)$ was assumed to be equal to 1.0, which supposes that $\mathrm{CH}_{4}$ transport across the PMOB is dominated by advection, a process that does not cause isotopic fractionation (Liptay et al., 1998; Stern et al., 2007). However, some studies have shown that this approach can underestimate $\mathrm{CH}_{4}$ oxidation by not taking into account diffusive flux (De Visscher et al., 2004; Gebert et al., 2011a). Diffusive fluxes can play a significant role in gas transport, particularly when the landfill site is equipped with a biogas collection system, which causes a decrease (even an inversion) of the pressure gradient between the waste mass and the atmosphere. 


\section{Results and Discussion}

\section{Oxidation efficiencies by mass balance of $\mathrm{CH}_{4}$}

Oxidation efficiencies calculated by mass balance $\left(f_{o_{-} M B}\right)$ in PMOB-2 during 2008 and 2009 are presented in Figure 2, which shows the evolution with time of $\mathrm{CH}_{4}$ loadings, outfluxes, oxidation rates and $f_{o_{-}} M B$ values for the entire 2008 and 2009 sampling periods. However, for the purpose of comparing mass balance data with those of stable isotopes, only the sampling dates in which both mass balance and stable isotope analysis were carried out are targeted in this discussion.

The methane loading into PMOB-2 in the beginning of the 2008 monitoring season was $9.3 \mathrm{~g} \mathrm{CH}_{4} \mathrm{~m}^{-2} \mathrm{~d}^{-1}$ and was increased steadily reaching a maximum of $820.0 \mathrm{~g} \mathrm{CH}_{4} \mathrm{~m}^{-2} \mathrm{~d}^{-1}$ at mid-October 2008. $f_{o_{-}}$MB values averaged $98.3 \pm 3.6 \%$ (average \pm standard deviation) for $\mathrm{n}=25$ observations performed throughout the summer and early fall (Cabral et al., 2010a). For example, the oxidation rate obtained on October 17, 2008 for PMOB-2 $\left(J_{o x}=\right.$ $800.4 \mathrm{~g} \mathrm{CH}_{4} \mathrm{~m}^{-2} \mathrm{~d}^{-1}$, Figure 2a) corresponds to an efficiency of $97.8 \%$ and is close to the maximum oxidation rate obtained for PMOB-2 in 2008, i.e. $804 \mathrm{~g} \mathrm{CH}_{4} \mathrm{~m}^{-2} \mathrm{~d}^{-1}$ (Cabral et al., 2010a). Such high oxidation rates are not usual, but have been found elsewhere (e.g. Gebert et al. (2006), Streese and Stegmann (2003) and Wilshusen et al. (2004)). In fact, some methane oxidation rates reported in the literature are limited to the low $\mathrm{CH}_{4}$ loadings to which covers were submitted. Therefore, it is possible that higher oxidation rates might have been obtained if higher loadings were applied. In the beginning of 2009, the methane loading into PMOB-2 was $8.0 \mathrm{~g} \mathrm{CH}_{4} \mathrm{~m}^{-2} \mathrm{~d}^{-1}$ and peaked at $580 \mathrm{~g} \mathrm{CH}_{4} \mathrm{~m}^{-2} \mathrm{~d}^{-1}$. The average of $f_{o_{-} M B}$ values was $92.1 \pm 14.2 \%(\mathrm{n}=22)$. The higher dispersion in these $f_{O_{-} M B}$ values was caused by lower efficiencies measured at the end of the monitoring season (i.e. October 2009). However, until the end of September 2009, oxidation efficiencies were higher than $90 \%$ for the majority of sampling dates (Figure $2 b$ ).

Oxidation efficiencies obtained for PMOB-3B in 2009 are shown in Figure 3. In the beginning of the 2009 monitoring season, the methane loading was $20.0 \mathrm{~g} \mathrm{CH}_{4} \mathrm{~m}^{-2} \mathrm{~d}^{-1}$ and had a peak of $352 \mathrm{~g} \mathrm{CH}_{4} \mathrm{~m}^{-2} \mathrm{~d}^{-1}$. $f_{O_{-}} M B$ values averaged $90.6 \pm 18.8 \%(\mathrm{n}=18)$. Similarly to PMOB-2, $f_{o_{-} M B}$ values greater than $90 \%$ were obtained until the end of September 2009. Stable isotope analyses were not performed in 2008 for PMOB-3B; therefore, oxidation efficiencies obtained by mass balance for 2008 are not presented herein.

The higher efficiencies $\left(f_{O_{-} M B}>90 \%\right)$ and oxidation rates reported for PMOB-2 and -3B (Figure 2 and Figure 3) can, among other factors, be associated with milder air temperatures prevailing during the summer, up to the beginning of October. Temperature profiles of PMOB-2 and -3B are presented in Figure 4. The sampling dates correspond to the days in which both mass balance and stable isotope analyses were performed. Surface temperatures are those of atmospheric air and the data in Figure 4 were recorded during the same period of the day when sampling and measurements were performed (i.e. $10 \mathrm{AM}$ to $12 \mathrm{PM}$ ). The atmospheric temperature averaged $12 \pm 10^{\circ} \mathrm{C}$ for the sampling dates of PMOB-2 and $11 \pm 5^{\circ} \mathrm{C}$ for those of PMOB-3B. Within the biocovers, temperatures were much higher (e.g. average equal to $20 \pm 11^{\circ} \mathrm{C}$ for PMOB-2 and $30 \pm 14^{\circ} \mathrm{C}$ for 
PMOB-3B at a depth of $0.10 \mathrm{~m}$ ). It is known that in such temperature conditions methanotrophic bacteria can oxidize the $\mathrm{CH}_{4}$ that migrates through the biocover (Chanton and Liptay, 2000; Stern et al., 2007).

During the warmer - thus dryer - periods, the degrees of saturation (moisture content) within the biocovers were low enough (between 40.0 and $80.0 \%$ ), allowing penetration of atmospheric air deep into the substrate (gas profiles not shown; for typical profiles in PMOB-2 see Cabral et al. (2010a) and for PMOB-3B see Cabral et al. (2010b)).

The oxidation efficiency obtained in PMOB-2 on October 23, 2009 was comparatively low at 45.5\% (Figure 2b). This can be associated with several causes, particularly the presence of a thin snow cover on the monitoring area that froze the surface of the soil (Figure 4a). A similar drop in efficiency was observed in PMOB-3B on October 1,2009 when $f_{o_{-} M B}=34.0 \%$ (Figure 3) and the atmospheric temperature was equal to $6^{\circ} \mathrm{C}$ (Figure $4 \mathrm{~b}$ ). Figure 4 shows that temperatures across the profiles were lower for these dates than for the others. These temperatures are well below the optimum zone for methane oxidation, i.e. 25 to $30^{\circ} \mathrm{C}$ (Chanton and Liptay, 2000; Stern et al., 2007). Despite the fact that under such cold temperatures methanotrophic activity is dramatically reduced (Chanton and Liptay, 2000; Einola, 2003; Stern et al., 2007), the data presented herein show that methane oxidation was still operative. The occurrence of methane oxidation under low temperatures is a phenomenon that is well documented by Einola et al. (2007). An increase in moisture near the surface due to snow melting during the day might have also been a complementary cause to the decrease in $\mathrm{CH}_{4}$ oxidation efficiency. However, gas profiles obtained on October 23, 2009 reveal significant $\mathrm{O}_{2}$ and $\mathrm{N}_{2}$ concentrations up to a depth of $0.20 \mathrm{~m}(7 \%$ for $\mathrm{O}_{2}$ and $12 \%$ for $\mathrm{N}_{2}$ ).

In spite of the low oxidation efficiency obtained in PMOB-2 on October 23, 2009, the respective oxidation rate of $173.5 \mathrm{~g} \mathrm{CH}_{4} \mathrm{~m}^{-2} \mathrm{~d}^{-1}$ is much higher than the average methane loading applied to cover systems in several Waste Management landfills with gas collection systems in the U.S. and Canada (approximately $28 \mathrm{~g} \mathrm{CH}_{4} \mathrm{~m}^{-2}$ $\mathrm{d}^{-1}$; personal communication with Terry Johnson, Waste Management). In addition, the oxidation rate for October 23, 2009 is within the order of magnitude of field values reported in the literature by Chanton et al. (2009). Accordingly, the oxidation rate of $84.6 \mathrm{~g} \mathrm{CH}_{4} \mathrm{~m}^{-2} \mathrm{~d}^{-1}$ obtained when the $\mathrm{CH}_{4}$ oxidation efficiency was lowest for PMOB-3B (October 1, 2009), can also be considered relatively high.

We can hypothesize that vegetation present on the biocovers could have contributed to the higher oxidation rates obtained in the field. It has been shown that vegetation can increase the substrate porosity by the formation of secondary macro-pores in the spreading roots zone and thus increase atmospheric $\mathrm{O}_{2}$ penetration in the soil (Bohn et al., 2011; Nagendran et al., 2006). Also, vegetation can contribute to the evapotranspiration of water generated by the $\mathrm{CH}_{4}$ oxidation process and precipitation (Huber-Humer and Lechner, 2003). In this study, no particular investigation was made concerning this matter.

\section{Oxidation efficiencies by stable isotopes}


The results of methane oxidation efficiencies obtained in 2008 and 2009 with the stable isotope method are shown in Table 1. The isotopic composition of $\mathrm{CH}_{4}$ in the anoxic zone, $\delta_{\mathrm{A}}$ (Eq. 2), was considered equal to the $\delta^{13} \mathrm{C}$ for the raw landfill biogas (Table 1), which was sampled from the biogas well feeding the PMOBs. In Eq. 2, $\delta_{\mathrm{E}}$, defined as the isotopic composition of the emitted $\mathrm{CH}_{4}$ (Chanton et al., 1999), was considered as the isotopic composition at each of the depths where efficiencies were calculated. The $\alpha_{o x}$ value determined from a laboratory incubation test was equal to 1.0258 at $20^{\circ} \mathrm{C}$. The $\alpha_{o x}$ values in Table 1 are those corrected for temperature using Eq. 4.

The results in Table 1 show that, in the majority of cases, the isotopic compositions at each of the several depths within the biocovers $\left(\delta_{\mathrm{E}}\right)$ increased from the bottom $(0.80 \mathrm{~m})$ towards the surface. This suggests that the transported $\mathrm{CH}_{4}$ became enriched in ${ }^{13} \mathrm{C}$ isotope as it migrated through the biocover to the atmosphere (Abichou et al., 2006); an enrichment caused by preferential consumption of the ${ }^{12} \mathrm{C}$ isotope of $\mathrm{CH}_{4}$ by methanotrophs (De Visscher et al., 2004).

However, loss of enrichment (i.e. depletion in $\delta^{13} \mathrm{C}$ value) as the biogas moved upwards was also observed on some dates (Table 1). Such losses occur mainly between shallow depths $(0.05-0.10 \mathrm{~m})$ and the surface, a phenomenon also reported elsewhere (Chanton et al., 2008a; De Visscher et al., 2004; Gebert et al., 2011a). For example, in PMOB-3B, on September 21, 2008 (Table 1), the isotopic composition of the gas at a depth of $0.10 \mathrm{~m}$ was $-40.5 \%$ and at a depth of $0.05 \mathrm{~m}$ decreased to $-50.5 \%$. Chanton et al. (2008a) observed more enrichment in isotope ${ }^{13} \mathrm{C}$ at $0.05-0.10 \mathrm{~m}$ depths, where $\delta^{13} \mathrm{C}$ values ranged from -46.0 to $-32.1 \%$ o than in emitted $\mathrm{CH}_{4}$, where $\delta^{13} \mathrm{C}$ values ranged from -56.5 to $-43.0 \delta^{13} \mathrm{C} \%$. In this study, loss of enrichment at shallow depths can be partly attributed to differences in diffusion coefficients between the two isotopes (Chanton et al., 2008a; De Visscher et al., 2004; Gebert et al., 2011a). The lighter isotope $\left({ }^{12} \mathrm{C}\right)$ diffuses within the air-filled pores of the soil at a faster rate $(1.9 \%$ according to Chanton et al. $(2008 \mathrm{a}))$ than the heavier one $\left({ }^{13} \mathrm{C}\right) .{ }^{12} \mathrm{C}$ is thus preferentially released to the atmosphere and results in loss of enrichment. This is why $\mathrm{CH}_{4}$ oxidation efficiencies can be underestimated using solely the difference between the $\delta^{13} \mathrm{C}$ from the anoxic zone and the emitted $\delta^{13} \mathrm{C}$ (Chanton et al., 2008a). Even in cases where advection is still the main transport phenomena of $\mathrm{CH}_{4}$, differential diffusion of the two isotopes can still play a role (Rannaud et al., 2009), particularly for soils whose air-filled porosities are high (Gebert et al., 2011a). The two other means of loss of enrichment, mix of oxidized (enriched $\delta^{13} \mathrm{C}$ ) and non-oxidized $\mathrm{CH}_{4}$, and differential flow path oxidation are discussed by Chanton et al. (2008a). Given the limited database of this study, it was not possible to investigate the causes of the observed loss of enrichment in detail.

The data in Table 1 indicate that $\mathrm{CH}_{4}$ oxidation efficiencies calculated with isotopic compositions of the samples taken as deep as 0.30 to $0.40 \mathrm{~m}$ were, for the majority of sampling dates, in the vicinity of $50 \%$. For example, on August 24, 2009 in PMOB-2, the $f_{o_{-} S I}$ value was 52.3\% and on September 21, 2009 in PMOB-3B, the $f_{o_{-} S I}$ value was $48.1 \%$ (both at a depth of $0.30 \mathrm{~m}$ ). For the same dates and depths, the $\mathrm{O}_{2}$ concentrations were equal to $0.9 \%$ and $0.4 \%$, respectively; while the $\mathrm{N}_{2}$ concentrations were $72.7 \%$ and $53 \%$, respectively. This clearly indicates that atmospheric air was able to reach this depth and that, despite the low concentrations of molecular oxygen, methanotrophic activity was still noticeable. 


\section{Adopted $\delta_{A}$ values}

Chanton and Liptay (2000) showed that the isotopic composition of raw biogas does not vary significantly with the seasons. In the present study, it was observed that the volumetric concentrations of $\mathrm{CH}_{4}, \mathrm{CO}_{2}$ and $\mathrm{O}_{2}$ at the biogas well, feeding the two experimental biocovers, did not change significantly throughout 2008 and 2009; in fact, the standard deviations are low, as indicated in Table 2. It was therefore decided to send only one set of triplicates for stable isotope analyses and adopt a single value of $\delta_{\mathrm{A}}$ for each year. The values of $\delta_{\mathrm{A}}$ shown in Table 1 are quite similar to those reported in the literature (Abichou, 2006; Chanton et al., 1999; Liptay et al., 1998).

\section{Reliability of $f_{\text {o_s }}$ considering potential errors in the estimation of $\alpha_{o x}$ and the possibility that $\alpha$ trans $>1.0$}

To calculate oxidation efficiencies, Cabral et al. (2010b) employed a $\alpha_{\text {ox }}$ equal to 1.0235, which was the average obtained from a literature review. The associated standard deviation was \pm 0.0047 (i.e. $\sim 0.5 \%$ ). Table 3 presents $f_{O_{-} S I}$ values calculated when this standard deviation is applied to the value of the $\alpha_{\mathrm{ox}}$ obtained from the incubation test and then corrected for temperature using Eq. 4. To simplify, only the values of samples at $0.10 \mathrm{~m}$ are presented. It can be observed that a mere $0.5 \%$ change in $\alpha_{o x}$ value resulted in an important dispersion in oxidation efficiencies. For example, the oxidation efficiency of 66.4\% obtained on August 24, 2009 for PMOB-2 might well have been $53.3 \%$ or $87.8 \%$, which is quite a wide dispersion. In addition, for two samples from PMOB-3B with high $f_{o_{-} S I}$ values $(87.3 \%$ and $78.9 \%$, Table 3$)$, oxidation efficiencies greater than $100 \%$ would be obtained following a mere reduction of $0.5 \%$ of the $\alpha_{\mathrm{ox}}$ value. However, in most cases involving laboratory test results, standard deviations greater than $0.5 \%$ are to be expected. As a consequence, greater dispersions than those reported above would be found. In the present study, only one test was performed to determine $\alpha_{\text {ox }}$; it is therefore not possible to evaluate the extent of the latter assertion.

In addition to the concern with the dispersion of $\alpha_{o x}$ values, consideration is due about the effect of the true value of $\alpha_{\text {trans, }}$, which, as mentioned above, may be greater than 1.0 (in cases where diffusion becomes important in the biocover). Acknowledging the fact that gas collection systems may reduce the relative importance of advective to diffusive transport, Chanton et al. (2011) proposed a procedure to re-evaluate $\alpha_{\text {trans }}$ values. Using a data set for several sites across the US, $\alpha_{\text {trans }}$ values as high as 1.018 were obtained. In some of the cases analyzed, the mere $1.8 \%$ difference from unity led to 3 - to 4.5 -fold increases in the calculated fraction of oxidized methane. Following the same procedure adopted by Chanton et al. (2011), a $\alpha_{\text {trans }}$ as high as $1.0103 \pm 0.0111$ was estimated. The efficiencies were then recalculated and a 1.6-fold increase was obtained. Considering the above, the approach adopted in the present study, i.e. $\alpha_{\text {trans }}=1.0$ can be considered conservative, because, if $\alpha_{\text {trans }}>1.0$ had been adopted, greater $f_{o_{-} S I}$ values would have been obtained. In other words, the oxidation efficiencies calculated here represent the lower limit of $\mathrm{CH}_{4}$ oxidation. Considering the added influence of the potential variability of $\alpha_{o x}$ (as discussed above), the dispersion in real values of $f_{o s}$ sI would be even greater. 


\section{Comparison between mass balance and stable isotope results}

As mentioned previously, samples taken inside flux chambers (thus at the surface) were quite diluted and their isotopic compositions could not be determined. Consequently, a straightforward comparison with mass balance results could not be made. Comparisons between oxidation efficiencies using the two methods were thus made using isotopic data for a depth of $0.10 \mathrm{~m}$. The $\mathrm{CH}_{4}$ loading in PMOB-2 attained $818.1 \mathrm{~g} \mathrm{CH}_{4} \mathrm{~m}^{-2} \mathrm{~d}^{-1}$ in October 2008 and the $f_{O_{-} M B}$ was $97.8 \%$ (Figure $2 \mathrm{a}$ ), whereas the $f_{o_{-} S I}$ value for $0.10 \mathrm{~m}$ was equal to $42.8 \%$ on Oct. 17 , 2008 (Table 1). In August 2009, the $\mathrm{CH}_{4}$ loading reached more than $200 \mathrm{~g} \mathrm{CH}_{4} \mathrm{~m}^{-2} \mathrm{~d}^{-1}$ and virtually all the $\mathrm{CH}_{4}$ was oxidized $\left(f_{O_{-} M B}=99.3 \%\right)$. For the same period, the $f_{o_{-} S I}$ value for $0.10 \mathrm{~m}$ was equal to $66.4 \%$ (Table 1$)$. Unfortunately, the data for $0.10 \mathrm{~m}$ on August 20, 2009 had to be discarded due to the abnormally high value of $\delta_{\mathrm{E}}(-26.8 \%)$; probably the result of an accidental contamination of the sample during sampling, storage or analysis. However, it can be expected that $f_{o_{-} S I}>54.5 \%$, which is the value of $f_{o_{-} S I}$ obtained at $0.30 \mathrm{~m}$ for this sampling date. On October 23, 2009, the temperature within PMOB-2 dropped to $0^{\circ} \mathrm{C}$ at the surface and $12.0^{\circ} \mathrm{C}$ at $0.10 \mathrm{~m}$, while the loading was still high $\left(381.5 \mathrm{~g} \mathrm{CH}_{4} \mathrm{~m}^{-2} \mathrm{~d}^{-1}\right)$. A drastic drop in $\mathrm{CH}_{4}$ oxidation efficiency ensued, with $f_{o_{-} M B}=45.5 \%$ and $f_{o_{-} S I}=18.8 \%$ at $0.10 \mathrm{~m}$.

In PMOB-3B, the loading reached $290.3 \mathrm{~g} \mathrm{CH}_{4} \mathrm{~m}^{-2} \mathrm{~d}^{-1}$ on September 21, 2009 (Figure 3), while $f_{o_{-}} S I$ was equal to $87.3 \%$ at $0.10 \mathrm{~m}$ and $f_{o_{-} M B}=99.0 \%$. Temperatures near the surface of PMOB-3B were high at the end September 2009 (e.g. $38.3^{\circ} \mathrm{C}$ and $36.7^{\circ} \mathrm{C}$ at the depth of $0.10 \mathrm{~m}$, Figure $4 \mathrm{~b}$ ), which may have contributed to the high $\mathrm{CH}_{4}$ oxidation efficiencies obtained. On October 1, 2009 the temperature dropped to $14.1^{\circ} \mathrm{C}$ in PMOB-3B, while the $\mathrm{CH}_{4}$ loading was still high $\left(\sim 250.0 \mathrm{~g} \mathrm{CH}_{4} \mathrm{~m}^{-2} \mathrm{~d}^{-1}\right)$, causing the significant drop in oxidation efficiency, with $f_{o_{-}} S I$ $=23.1 \%$ and $f_{O_{-} M B}=34.0 \%$ (Figure 3 ).

Considering the above, one may observe a clear discrepancy between oxidation efficiencies calculated using mass balance and stable isotopes (data at $0.10 \mathrm{~m}$ depth). A simple statistical analysis was performed to evaluate the quality of the correlation between mass balance and stable isotope results. The coefficient of determination, $R^{2}$, obtained was equal to 0.558 . Such a low $R^{2}$ value clearly shows that the correlation is very weak and may result from several causes. The most important one is possibly related to the fact that the most active zone for $\mathrm{CH}_{4}$ oxidation in biocovers is located very near the surface, where $\mathrm{O}_{2}$ availability is greater (Czepiel et al., 1996; Jones and Nedwell, 1993; Jugnia et al., 2008). In fact, as $\mathrm{CH}_{4}$ migrates through the last stretch of the cover, a significant portion of it can still be oxidized. As a consequence, efficiencies calculated using stable isotope data from samples taken at $0.10 \mathrm{~m}$ can - at most - provide the lowest estimate possible for the actual efficiency of the system. Powelson et al. (2007) found that $\mathrm{CH}_{4}$ oxidation efficiencies evaluated by stable isotopes averaged only $45.5 \%$ of those calculated by mass balance in compost and sand biofilters. In column tests, De Visscher et al. (2004) found differences of a factor of 2-4 between mass balance and stable isotope results. Further studies comparing these methodologies are needed. In a recent study of $\mathrm{CH}_{4}$ oxidation efficiencies calculated using $\mathrm{CH}_{4}$ samples taken at the surface, Widory et al. (2012) found that the mass balance and the stable isotope approaches were rather similar (their coefficient of determination was equal to 0.91 ). 


\section{Summary and Conclusions}

Microbial $\mathrm{CH}_{4}$ oxidation efficiencies in two experimental biocovers were evaluated using two methodologies: mass balance calculations and stable isotopes. The former used $\mathrm{CH}_{4}$ loading and surface flux data, whereas efficiencies by stable isotopes were calculated using isotope compositions taken from several depths within the biocovers.

For the thicker biocover (PMOB-2), mass balance-derived efficiencies were always greater than $95 \%$ for the targeted sampling dates (under loadings as high as $818 \mathrm{~g} \mathrm{CH}_{4} \mathrm{~m}^{-2} \mathrm{~d}^{-1}$ ), except during a cold day (atmospheric temperature $\sim 0^{\circ} \mathrm{C}$ ), when it dropped to $45.5 \%$. Despite this drop, the methane oxidation rate was still considerable (173.5 $\left.\mathrm{g} \mathrm{CH}_{4} \mathrm{~m}^{-2} \mathrm{~d}^{-1}\right)$. The highest efficiency calculated using stable isotopes data was $66.4 \%$ and the lowest $18.8 \%$; both at a depth of $0.10 \mathrm{~m}$. For the thinner biocover (PMOB-3B), mass balance-derived efficiencies were greater than $92 \%$ (under loadings as high as $290 \mathrm{~g} \mathrm{CH}_{4} \mathrm{~m}^{-2} \mathrm{~d}^{-1}$ ), except during a cold sampling date (atmospheric temperature $=6^{\circ} \mathrm{C}$ ), when it dropped to $34 \%$ (associated with an oxidation rate equal to $84.6 \mathrm{~g}$ $\left.\mathrm{CH}_{4} \mathrm{~m}^{-2} \mathrm{~d}^{-1}\right)$. The highest methane oxidation efficiency calculated using stable isotope data was $87.3 \%$, while the lowest was $23.1 \%$; always at $0.10 \mathrm{~m}$.

The correlation between $\mathrm{CH}_{4}$ oxidation efficiencies using the two methods is quite weak $\left(R^{2}=0.558\right)$, which can be partly attributed to the fact that a significant portion of the $\mathrm{CH}_{4}$ oxidation occurs within the top-most $0.10 \mathrm{~m}$, where $\mathrm{O}_{2}$ availability for methanotrophic activity is greater. As a consequence, a straightforward comparison between the two was not possible. If the difficulties often reported in the literature concerning the reliability of $\delta^{13} \mathrm{C}$ of $\mathrm{CH}_{4}$ from surface samples (such as loss of enrichment due, among other causes, to diffusive fractionation) are not overcome, it will continue to be difficult to compare the actual value of isotope-derived oxidation efficiencies against more straightforward methods, such as mass balance calculations in controlled experiments.

In addition, the stable isotopes method presents a high sensitivity to small variations in key parameters. For example, a mere $\pm 0.5 \%$ in the value of $\alpha_{o x}$ results in oxidation efficiencies that can vary from $53.3 \%$ to $87.8 \%$. Also, a mere increase of $1.1 \%$ in the $\alpha_{\text {trans }}$ value can result in a 1.6 -fold increase in $\mathrm{CH}_{4}$ oxidation efficiency, indicating that the widespread use of $\alpha_{\text {trans }}$ equal to unity is very conservative.

The mass balance method is not a viable alternative except in special circumstances such as those found in our experimental plots where loadings are known. In addition, it would have to be accompanied by a well implemented and verified methodology to measure outfluxes (or surface fluxes). So, the search continues for a reliable technique to estimate $\mathrm{CH}_{4}$ oxidation efficiencies in landfill covers. Recently, Gebert et al. (2011b) proposed a method based on $\mathrm{CO}_{2}$ and $\mathrm{CH}_{4}$ measurements. Its value and limitations have to be further investigated. So far, only the stable isotope method is readily available. The present paper questioned its reliability. 


\section{Acknowledgements}

This study was supported by a Cooperative Research and Development Grant from NSERC and Waste Management (grant \# CRD 379885-08). The invaluable help of Jean-Guy Lemelin, technician must be acknowledged. We also are grateful to the personnel of DeltaLab (Geological Survey of Canada, GSC-Quebec) and of the G.G. Hatch Lab (University of Ottawa).

\section{References}

Abichou T., Clark J., Chanton J. (2011). Reporting central tendencies of chamber measured surface emission and oxidation. Waste Management 31, 1002-1008.

Abichou T., Powelson D., Chanton J., Escoriaza S., Stern J. (2006). Characterization of methane flux and oxidation at a solid waste landfill. Journal of Environmental Engineering 132, 220-228.

Abichou T., Chanton, J., Powelson, D., Fleiger, J., Escoriaza, S., Lei, Y., and, Stern, J. (2006). Methane flux and oxidation at two types of intermediate landfill covers. Waste Management 26, 1305-1312.

Bogner J.E., Matthews E. (2003). Global Methane Emissions from Landfills : New Methodology and Annual Estimates 1980-1996. Global Biogeochemical Cycles 17, 1065-1083.

Bohn S., Gebert J., Jager J. (2011). The effect of vegetation on microbial methane oxidation, XIII International Waste Management and Landfill Symposium, Cisa, S. Margherita di Pula - Cagliari, Sardinia, Italy.

Burnotte F., Cabral A.R., Lefebvre G. (2005). A Simple Field Method to Qualify the State of Saturation in Capillary Barriers. Geotechnical Testing Journal 28, 1-5.

Cabral A.R., Tremblay P., Lefebvre G. (2004). Determination of the diffusion coefficient of oxygen for a cover system composed of pulp and paper residues. Geot. Testing J. 27, 184-197.

Cabral A.R., Moreira J.F., Jugnia L.B. (2010a). Biocover Performance of Landfill Methane Oxidation: Experimental Results. Journal of Environmental Engineering, ASCE 138, 785-793. DOI: 10.1061/(ASCE)EE.1943-7870.0000182.

Cabral A.R., Capanema M.A., Gebert J., Moreira J.F., Jugnia L.B. (2010b). Quantifying microbial methane oxidation efficiencies in two experimental landfill biocovers using stable isotopes. Water, Air, and Soil Pollution 209, 157-172. DOI: DOI 10.1007/s11270-009-0188-4

Chanton J., Abichou T., Langford C., Hater G., Green R., Goldsmith D., Swan N. (2011). Landfill Methane Oxidation Across Climate Types in the U.S. Environmental Science \& Technology 45, 313-319. DOI: 10.1021/es101915r.

Chanton J.P., Liptay K. (2000). Seasonal Variation in Methane Oxidation in a Landfill Cover Soil as Determined by an In situ Stable Isotope Technique. Global Biogeochem. Cycles 14, 51-60.

Chanton J.P., Rutkowski C.M., Mosher B. (1999). Quantifying methane oxidation from landfills using stable isotope analysis of downwind plumes. Environmental Science and Technology 33, 3755-3760.

Chanton J.P., Powelson D.K., Green R.B. (2009). Methane oxidation in landfill soils, is a 10\% default value reasonable? . Journal of Environmental Quality 38, 654-663.

Chanton J.P., Powelson D.K., Abichou T., Hater G. (2008a). Improved field methods to quantify methane oxidation in landfill cover materials using stable carbon isotopes. Environmental Science and Technology 42, 665-670. 
Chanton J.P., Powelson D.K., Abichou T., Fields D., Green R. (2008b). Effect of temperature and oxidation rate on carbon-isotope fractionation during methane oxidation by landfill cover materials. Environmental Science and Technology 42, 7818-7823.

Czepiel P., Mosher B., Crill P., Harriss R. (1996). Quantifying the effect of oxidation on landfill methane emissions. Journal of Geophysical Research 101, 16721-16729.

De Visscher A., De Poureq I., Chanton J. (2004). Isotope fractionation effects by diffusion and methane oxidation in landfill cover soils. Journal of Geophysical Research 109, 8 pp.

De Visscher A., Thomas D., Boeckx P., Van Cleemput O. (1999). Methane oxidation in simulated landfill cover soil environments. Environmental Science and Technology 33, 1854-1859.

Einola J.-K.M., Kettunen R.H., Rintala J.A. (2007). Responses of methane oxidation to temperature and water content in cover soil of a boreal landfill. Soil Biology and Biochemistry 39, 1156-1164.

Einola J.-K.M., Sormunen, K. M. and Rintala, J. A.,. (2003). Seasonal Variation of Methane, Nitrous Oxide and Carbon Dioxide Emissions and Methane-Oxidising Activity at a Northern Landfill. Proceedings Sardinia 2003, Ninth International Waste Management and Landfill Symposium.

Gebert J., Groengroeft A. (2006). Performance of a passively vented field-scale biofilter for the microbial oxidation of landfill methane. Waste Management 26, 399-407.

Gebert J., Streblow C., Knoblauch C., Pfeiffer E.-M. (2011a). Effect of gas transport on fractionation of carbon stable isotopes related to the microbial oxidation of methane in landfill cover soils, XIII International Waste Management and Landfill Symposium, S. Margherita di Pula - Cagliari, Sardinia, Italy.

Gebert J., Rower I.U., Scharff H., Roncato C.D.L., Cabral A.R. (2011b). Can soil gas profiles be used to assess microbial CH4 oxidation in landfill covers? Waste Management 31, 987-994.

Gebert J., Singh, B. K., Pan, Y., Bodrossy, L. . (2009). Activity and structure of methanotrophic communities in landfill cover soils. Environmental Microbiology Reports 1, 414-423. DOI: 10.1111/j.17582229.2009.00061.x.

Hilger H., Humer M. (2003). Biotic Landfill Cover Treatments for Mitigating Methane Emissions. Environmental Monitoring and Assessment 84, 71-84.

Huber-Humer M., Lechner P. (2003). Effect of methane oxidation on the water balance of the landfill cover and the vegetation layer, Ninth International Waste Management and Landfill Symposium, S. Margherita di Pula, Cagliari, Italy.

Humer M., Lechner P. (1999). Methane oxidation in compost cover layers in landfills, 7th International Waste Management and Landfill Symposium, Sta Margarita di Pula, Italy. pp. 403-410.

Humer M., Lechner P. (2001). Microbial Methane Oxidation for the Reduction of Landfill Gas Emissions. Journal of Solid Waste Technology and Management Vol. 27, 146-151.

IPCC. (2007). Climate change 2007: Mitigation. Contr. Working Group III to the $4^{\text {th }}$ Assess Report of the IPCC, in: B. Metz, et al. (Eds.), , Intergovernmental Panel on Climate Change, Cambridge, United Kingdom and New York, NY, USA.

Iranpour R., Cox H.H.J., Deshusses M.A., Schroeder E.D. (2005). Literature review of air pollution control biofilters and biotrickling filters for odor and volatile organic compound removal. Environmental Progress 24, 254-267.

Jones H.A., Nedwell D.B. (1993). Methane emission and methane oxidation in landfill cover soil. FEMS Microbiol. Ecol. 102, 185-195.

Jugnia L.-B., Cabral A.R., Greer C.W. (2008). Biotic methane oxidation within an instrumented experimental landfill cover. Ecological Engineering 33, 102-109. 
Jugnia L.-B., Ait-Benichou S., Fortin N., Cabral A.R., Greer C.W. (2009). Diversity and dynamics of methanotrophs within an experimental landfill cover soil. Soil Science Society of America Journal 73, $1479-1487$.

Liptay K., Chanton J., Czepiel P., Mosher B. (1998). Use of stable isotopes to determine methane oxidation in landfill cover soils. Journal of Geophysical Research 103, 8243-50.

Nagendran R., Selvam A., Joseph K., Chiemchaisri C. (2006). Phytoremediation and rehabilitation of municipal solid waste landfills and dumpsites: A brief review. Waste Management 26, 1357-1369.

Powelson D.K., Chanton J.P., Abichou T. (2007). Methane oxidation in biofilters measured by mass-balance and stable isotope methods. Environmental Science and Technology 41, 620-625.

Powelson D.K., Chanton J., Abichou T., Morales J. (2006). Methane oxidation in water-spreading and compost biofilters. Waste Management and Research 24, 528-536.

Rannaud D., Cabral A., Allaire S.E. (2009). Modeling methane migration and oxidation in landfill cover materials with TOUGH2-LGM. Water, Air, and Soil Pollution 198, 253-267.

Roncato C., Cabral A. (2012). Evaluation of Methane Oxidation Efficiency of Two Biocovers: Field and Laboratory Results. Journal of Environmental Engineering 138, 164-173. DOI: doi:10.1061/(ASCE)EE.1943-7870.0000475.

Spokas K., Bogner J., Chanton J.P., Morcet M., Aran C., Graff C., Golvan Y.M.-L., Hebe I. (2006). Methane mass balance at three landfill sites: What is the efficiency of capture by gas collection systems? Waste Mgmt 26, 516-525.

Stern J.C., Chanton J., Abichou T., Powelson D., Yuan L., Escoriza S., Bogner J. (2007). Use of a biologically active cover to reduce landfill methane emissions and enhance methane oxidation. Waste Management $27,1248-1258$.

Streese J., Stegmann R. (2003). Microbial oxidation of methane from old landfills in biofilters. Waste Management 23, 573-580.

USEPA. (2011). Inventory of U.S. Greenhouse Gas Emissions and Sinks: 1990 - 2009, U.S. Environmental Protection Agency, Washington. pp. 459.

Widory D., Proust E., Bellenfant G., Bour O. (2012). Assessing methane oxidation under landfill covers and its contribution to the above atmospheric CO2 levels: The added value of the isotope (I' $13 \mathrm{C}$ and $\hat{I}^{\prime} 18 \mathrm{O}$ $\mathrm{CO} 2$; Î'13C and Î'D CH4) approach. Waste Management.

Wilshusen J.H., Hettiaratchi J.P.A., Stein V.B. (2004). Long-term behavior of passively aerated compost methanotrophic biofilter columns. Waste Management 24, 643-653. 


\section{List of tables:}

Table 1. Oxidation Efficiencies Obtained with the Stable Isotopes Method.

Table 2. Average Concentrations of $\mathrm{CH}_{4}, \mathrm{CO}_{2}$ and $\mathrm{O}_{2}$ from Raw Biogas.

Table 3. Variations in $\alpha_{o x}$ Value $( \pm 0.5 \%)$ and Changes in Oxidation Efficiencies $\left(f_{o S} S I\right)$.

\section{List of figures:}

Figure 1. Configuration and instrumentation of a profile of PMOB-2 and -3B.

Figure 2 : Oxidation efficiencies obtained in PMOB-2 by mass balance in 2008 and 2009. (a) from Cabral et al. (2010a) and (b) from Roncato and Cabral (2012).

Figure 3: Oxidation efficiencies obtained in PMOB-3B by mass balance in 2009 (from Roncato and Cabral (2012)).

Figure 4: Temperature profiles for PMOB-2 (a) and -3B (b) 


\begin{tabular}{|c|c|c|c|c|c|c|c|c|}
\hline $\begin{array}{l}\text { Sampling } \\
\text { dates }\end{array}$ & $\begin{array}{l}\text { PMOB } \\
\text { (Profile) }\end{array}$ & $\begin{array}{l}\text { Depth } \\
\text { (m) }\end{array}$ & $\begin{array}{l}\mathrm{CH}_{4} \\
(\%)\end{array}$ & $\begin{array}{c}\delta^{13} \mathrm{C} \text { of } \mathrm{CH}_{4} \\
\left(\delta_{E}\right) \\
(\% \text { VPDB })\end{array}$ & $\begin{array}{c}\delta^{13} \mathrm{C} \text { of } \mathrm{CH}_{4} \\
\left(\delta_{\mathrm{A}}\right) \\
(\% \mathrm{VPDB})^{\mathrm{a}}\end{array}$ & $\begin{array}{c}\text { Temperature } \\
\left({ }^{\circ} \mathrm{C}\right)\end{array}$ & $\begin{array}{c}\text { Corr. } \\
\boldsymbol{\alpha}_{0 \mathrm{x}}\end{array}$ & $\begin{array}{l}f_{o_{-}} S I \\
(\%)\end{array}$ \\
\hline \multirow{4}{*}{ Oct. 8,2008} & \multirow{4}{*}{$\begin{array}{l}\text { PMOB-2 } \\
\text { (P3) }\end{array}$} & 0.10 & 1.4 & -45.5 & -57.5 & 12.4 & 1.0288 & 41.7 \\
\hline & & 0.20 & 2.8 & -44.7 & -57.5 & 16.1 & 1.0273 & 47.0 \\
\hline & & 0.40 & 15.2 & -45.7 & -57.5 & 17.1 & 1.0269 & 43.9 \\
\hline & & 0.80 & 52.7 & -54.6 & -57.5 & 18.0 & 1.0266 & 11.0 \\
\hline \multirow{5}{*}{ Oct. 17, 2008} & \multirow{5}{*}{$\begin{array}{l}\text { PMOB-2 } \\
\text { (P1) }\end{array}$} & 0.05 & 2.9 & -43.1 & -57.5 & 9.2 & 1.0300 & 47.8 \\
\hline & & 0.10 & 2.9 & -45.3 & -57.5 & 12.9 & 1.0286 & 42.8 \\
\hline & & 0.30 & 7.2 & -54.5 & -57.5 & 15.7 & 1.0275 & 10.8 \\
\hline & & 0.40 & 18.2 & -54.4 & -57.5 & 16.2 & 1.0273 & 11.3 \\
\hline & & 0.80 & 50.0 & -55.8 & -57.5 & 16.8 & 1.0271 & 6.3 \\
\hline \multirow{4}{*}{ Aug. 20, 2009} & \multirow{4}{*}{$\begin{array}{l}\text { PMOB-2 } \\
\text { (P4) }\end{array}$} & 0.10 & 1.7 & -26.8 & -56.8 & 32.3 & 1.0210 & $100.0^{\mathrm{b}}$ \\
\hline & & 0.30 & 19.6 & -45.0 & -56.8 & 30.2 & 1.0218 & 54.5 \\
\hline & & 0.40 & 19.4 & -44.8 & -56.8 & 27.3 & 1.0229 & 52.5 \\
\hline & & 0.80 & 61.1 & -56.4 & -56.8 & 23.9 & 1.0243 & 1.7 \\
\hline \multirow{4}{*}{ Aug. 24, 2009} & \multirow{4}{*}{$\begin{array}{l}\text { PMOB-2 } \\
\text { (P4) }\end{array}$} & 0.10 & 1.8 & -42.9 & -56.8 & 32.4 & 1.0210 & 66.4 \\
\hline & & 0.30 & 2.2 & -45.4 & -56.8 & 29.8 & 1.0220 & 52.3 \\
\hline & & 0.60 & 15.2 & -47.5 & -56.8 & 26.2 & 1.0234 & 40.0 \\
\hline & & 0.80 & 54.5 & -56.9 & -56.8 & 24.8 & 1.0239 & 0.0 \\
\hline \multirow{3}{*}{ Oct. 23, 2009} & \multirow{3}{*}{$\begin{array}{l}\text { PMOB-2 } \\
\text { (P4) }\end{array}$} & 0.05 & 5.9 & -42.7 & -56.8 & 5.8 & 1.0314 & 45.0 \\
\hline & & 0.10 & 49.3 & -51.4 & -56.8 & 12.0 & 1.0289 & 18.8 \\
\hline & & 0.80 & 64.0 & -56.3 & -56.8 & 16.6 & 1.0271 & 2.0 \\
\hline \multirow{3}{*}{ Sept. 21, 2009} & \multirow{3}{*}{$\begin{array}{l}\text { PMOB-3B } \\
\text { (P3) }\end{array}$} & 0.05 & 0.9 & -50.5 & -56.8 & 29.2 & 1.0222 & 28.5 \\
\hline & & 0.10 & 6.5 & -40.5 & -56.8 & 38.3 & 1.0187 & 87.3 \\
\hline & & 0.30 & 19.2 & -47.3 & -56.8 & 35.0 & 1.0200 & 48.1 \\
\hline \multirow{3}{*}{ Sept. 24, 2009} & \multirow{3}{*}{$\begin{array}{l}\text { PMOB-3B } \\
\text { (P3) }\end{array}$} & 0.05 & 3.5 & -34.3 & -56.8 & 25.3 & 1.0237 & 94.9 \\
\hline & & 0.10 & 8.9 & -41.6 & -56.8 & 36.7 & 1.0193 & 78.9 \\
\hline & & 0.30 & 38.8 & -47.9 & -56.8 & 35.4 & 1.0198 & 45.1 \\
\hline \multirow{3}{*}{ Oct. 1, 2009} & \multirow{3}{*}{$\begin{array}{l}\text { PMOB-3B } \\
\text { (P3) }\end{array}$} & 0.05 & 18.4 & -52.0 & -56.8 & 10.0 & 1.0297 & 16.3 \\
\hline & & 0.10 & 35.6 & -50.4 & -56.8 & 14.1 & 1.0281 & 23.1 \\
\hline & & 0.30 & 56.0 & -51.9 & -56.8 & 17.4 & 1.0268 & 18.4 \\
\hline
\end{tabular}

${ }^{a} \mathrm{~A}$ single value to represent $\delta_{\mathrm{A}}$ for each year was adopted. See discussion below.

${ }^{\mathrm{b}}$ Actual value $>100 \%$ due to the abnormally high value of $\delta_{\mathrm{E}}$.

\section{Table 1.}




\begin{tabular}{llllll}
\hline Monitoring campaign & $\mathbf{n}$ & $\mathbf{C H}_{\mathbf{4}} \mathbf{( \% )}$ & $\mathbf{C O}_{\mathbf{2}} \mathbf{( \% )}$ & $\mathbf{O}_{\mathbf{2}} \mathbf{( \% )}$ & $\boldsymbol{\Sigma}$ Concentr. $(\mathbf{\%})^{\mathbf{2}}$ \\
\hline 2008 & 23 & $60.9 \pm 2.2^{1}$ & $37.3 \pm 8.2$ & $1.9 \pm 7.5$ & 100.1 \\
2009 & 22 & $62.8 \pm 1.9$ & $40.1 \pm 4.9$ & $0.6 \pm 0.7$ & 103.5 \\
\hline
\end{tabular}

${ }^{1}$ Average \pm standard deviation.

${ }^{2}$ Sums exceeded $100 \%$ because of analytical instrument error $\left(2 \%\right.$ for $\mathrm{CH}_{4}$ and $\mathrm{CO}_{2}$, and $1 \%$ for $\left.\mathrm{O}_{2}\right)$.

Table 2. 


\begin{tabular}{|c|c|c|c|c|c|c|c|c|c|c|}
\hline Sampling dates & PMOB (Profile) & $\begin{array}{c}\text { Depth } \\
\text { (m) }\end{array}$ & $\begin{array}{r}\text { Corr. } \alpha_{0 x} \\
\text { (Tal }\end{array}$ & $\begin{array}{l}f_{o \_s I}(\%) \\
\text { le } 1)\end{array}$ & $\begin{array}{c}\text { Corr. } \alpha_{o x} \\
+0.5 \%\end{array}$ & $f_{o}^{+}{ }_{-} S I(\%)$ & $\%$ decrease in $f_{o_{-}} S I$ & $\begin{array}{c}\text { Corr. } \alpha_{o x} \\
-\mathbf{0 . 5 \%}\end{array}$ & $f_{o_{-}}^{-} S I(\%)$ & $\%$ increase in $f_{o_{-} S I}$ \\
\hline Oct. 8, 2008 & PMOB-2 (P3) & 0.10 & 1.0288 & 41.7 & 1.0339 & 35.4 & 15.1 & 1.0236 & 50.7 & 21.7 \\
\hline Oct. 17,2008 & PMOB-2 (P1) & 0.10 & 1.0286 & 42.8 & 1.0337 & 36.3 & 15.2 & 1.0235 & 52.1 & 21.9 \\
\hline Aug. 20, 2009 & PMOB-2 (P4) & 0.10 & 1.0210 & $>100$ & \multicolumn{6}{|c|}{ (1) } \\
\hline Aug. 24, 2009 & PMOB-2 (P4) & 0.10 & 1.0210 & 66.4 & 1.0261 & 53.3 & 19.7 & 1.0158 & 87.8 & 32.4 \\
\hline Oct. 23, 2009 & PMOB-2 (P4) & 0.10 & 1.0289 & 18.8 & 1.0340 & 16.0 & 15.1 & 1.0238 & 22.9 & 21.6 \\
\hline Sept. 21, 2009 & PMOB-3B (P3) & 0.10 & 1.0187 & 87.3 & 1.0238 & 68.5 & 21.5 & 1.0136 & $>100$ & $(1)$ \\
\hline Sept. 24, 2009 & PMOB-3B (P3) & 0.10 & 1.0193 & 78.9 & 1.0244 & 62.3 & 21.0 & 1.0142 & $>100$ & (1) \\
\hline Oct. 1, 2009 & PMOB-3B (P3) & 0.10 & 1.0281 & 23.1 & 1.0332 & 19.5 & 15.4 & 1.0230 & 28.2 & 22.3 \\
\hline
\end{tabular}

(1) Meaningless.

Table 3. 


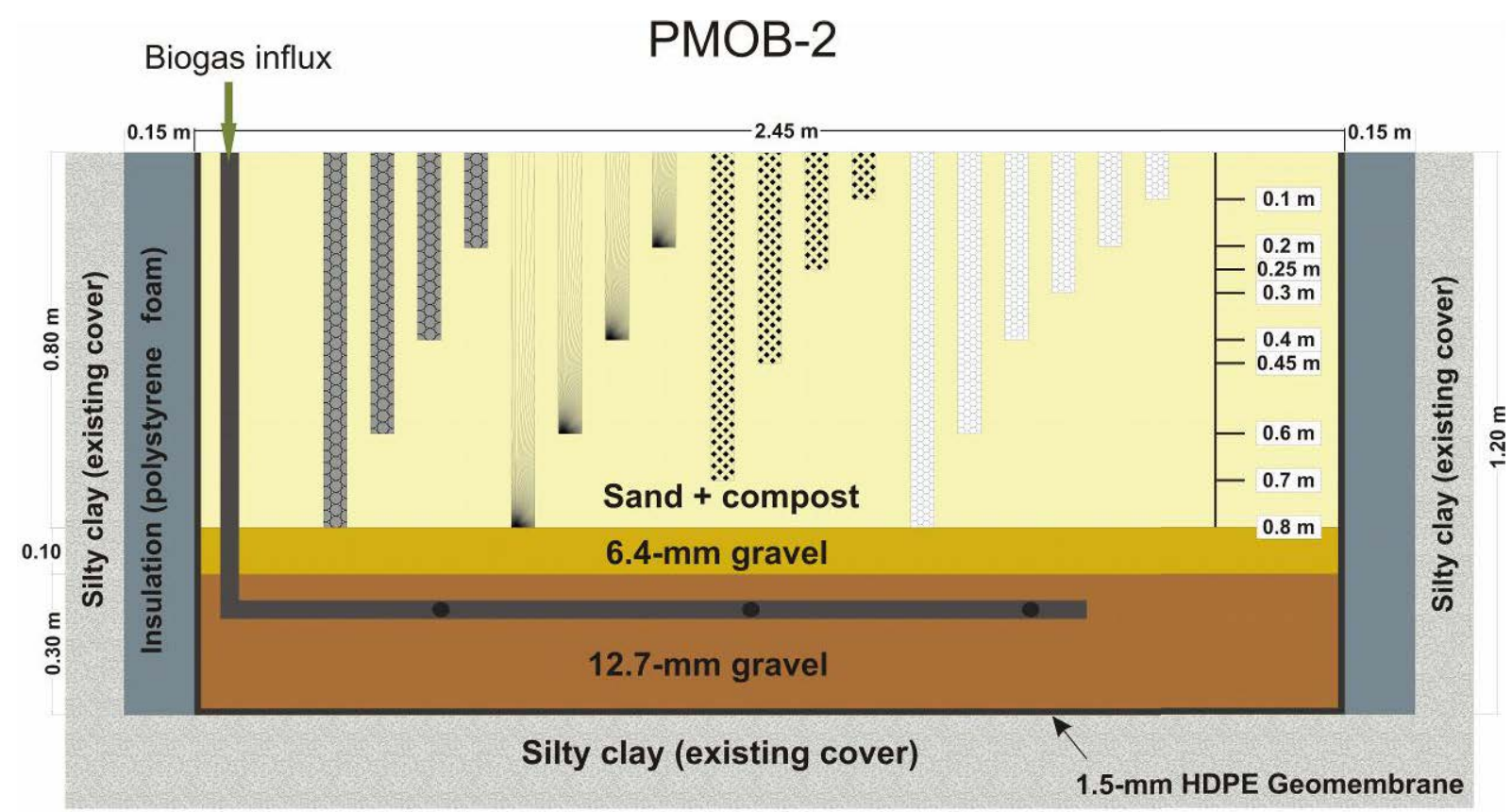

PMOB-3B

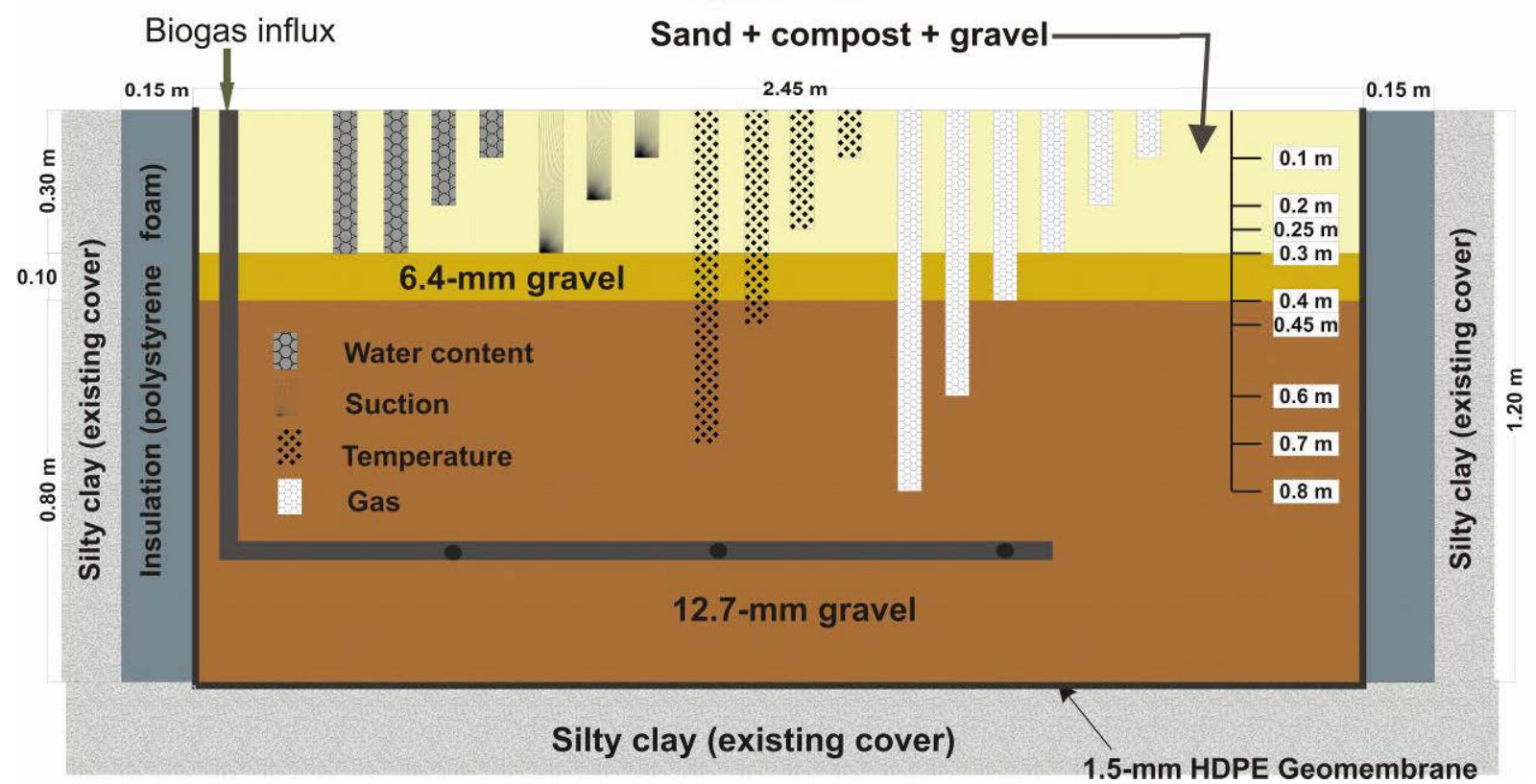

Figure 1. 


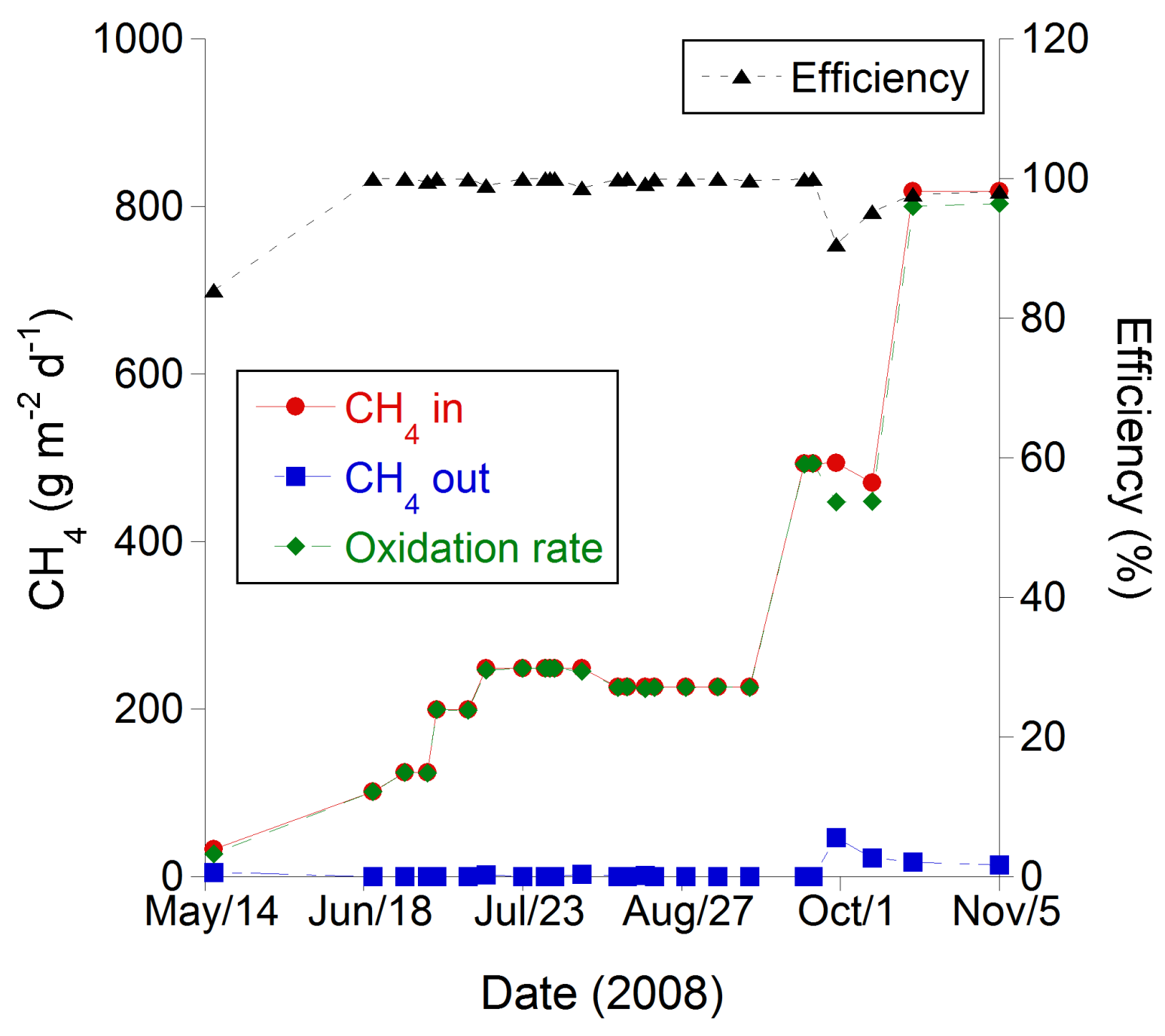

Figure 2a. 


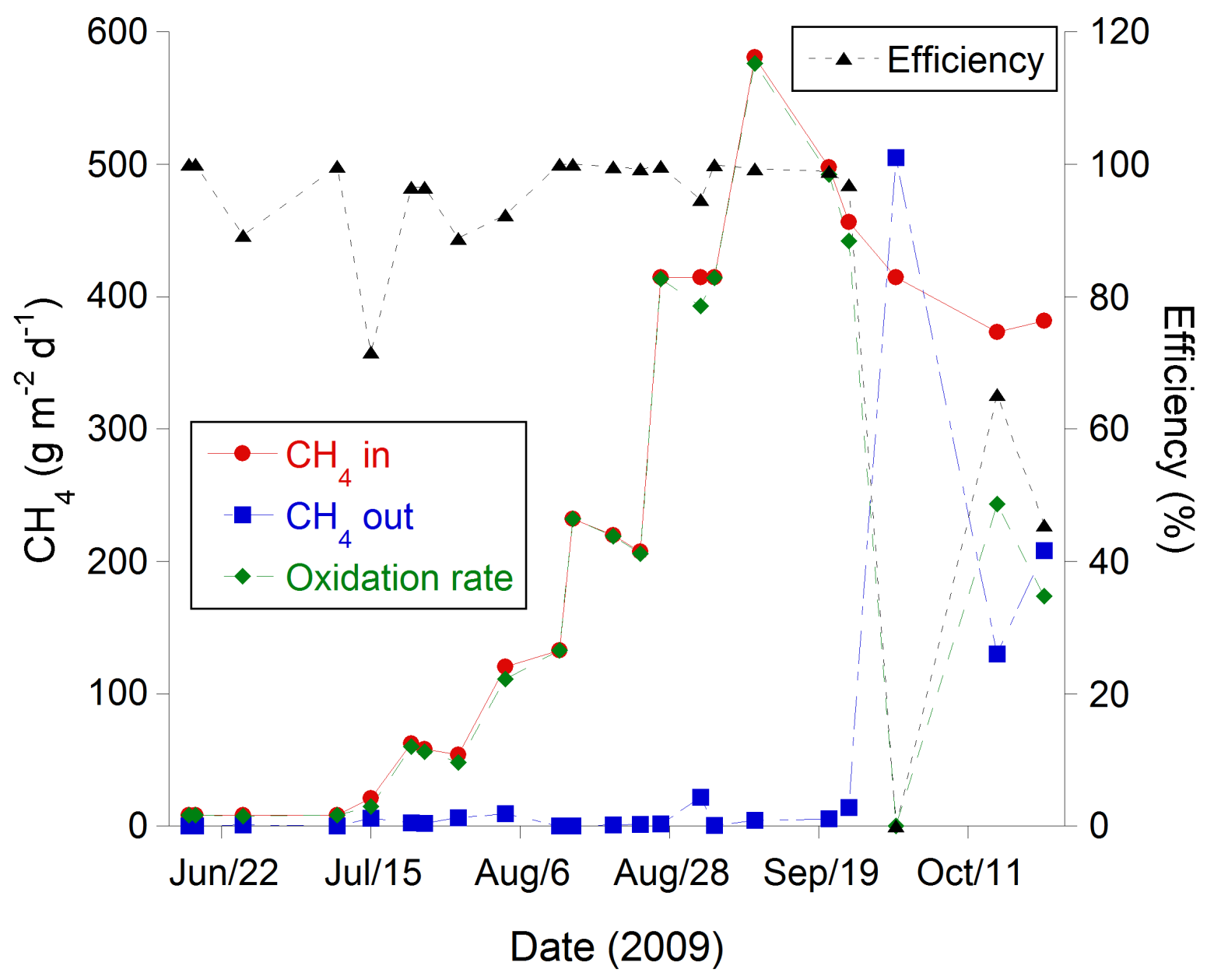

Figure 2b. 


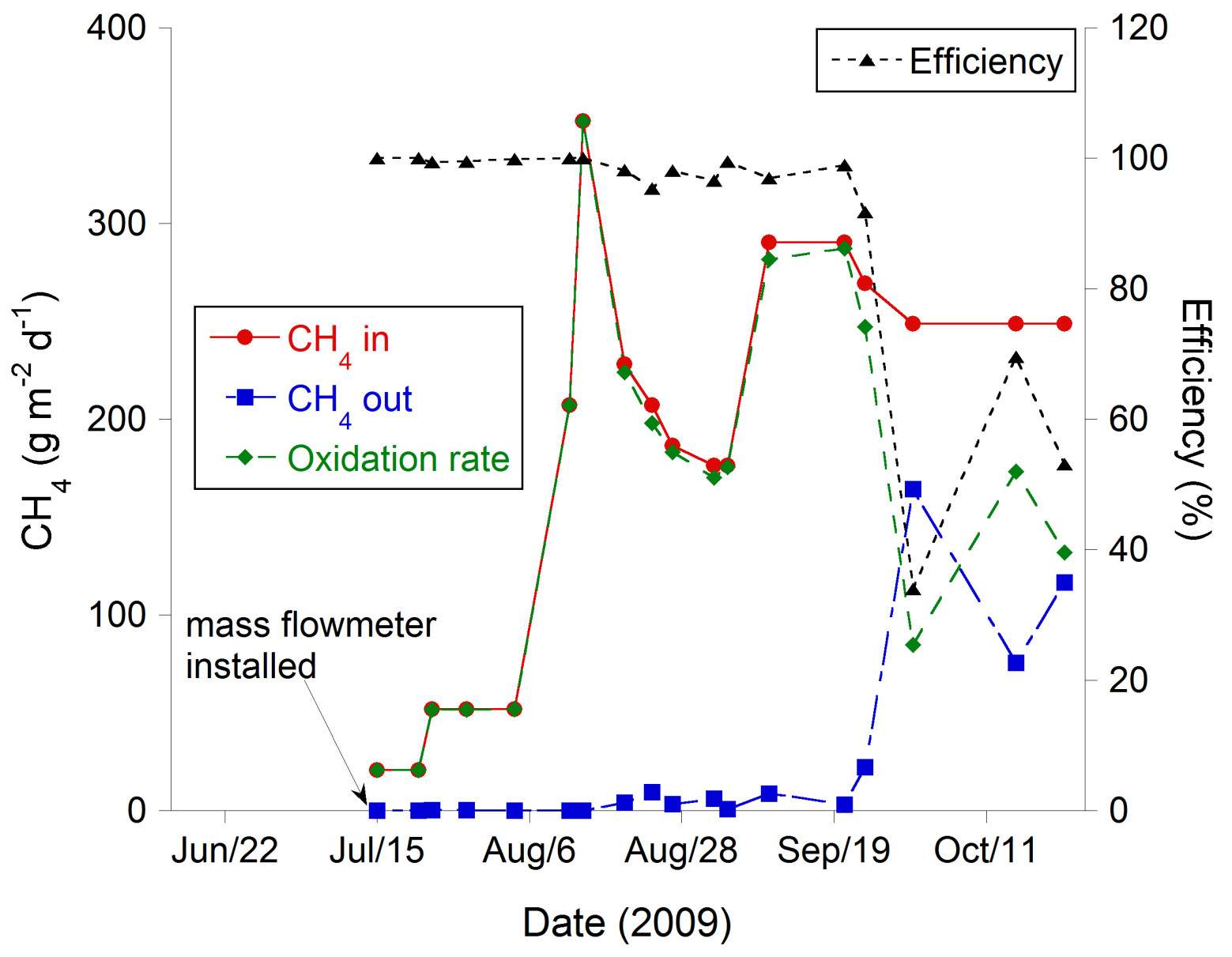

Figure 3. 


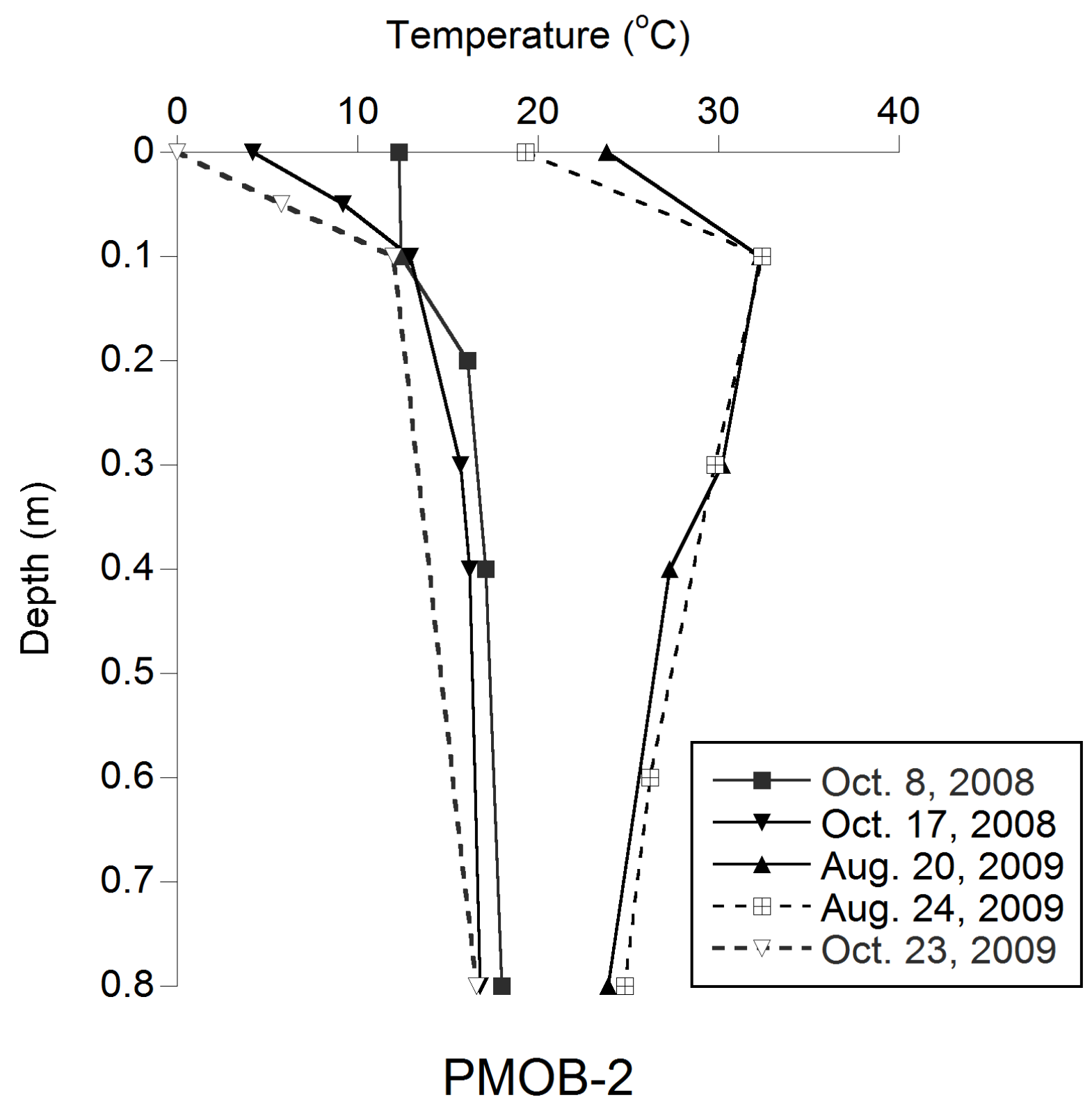

Figure 4a. 


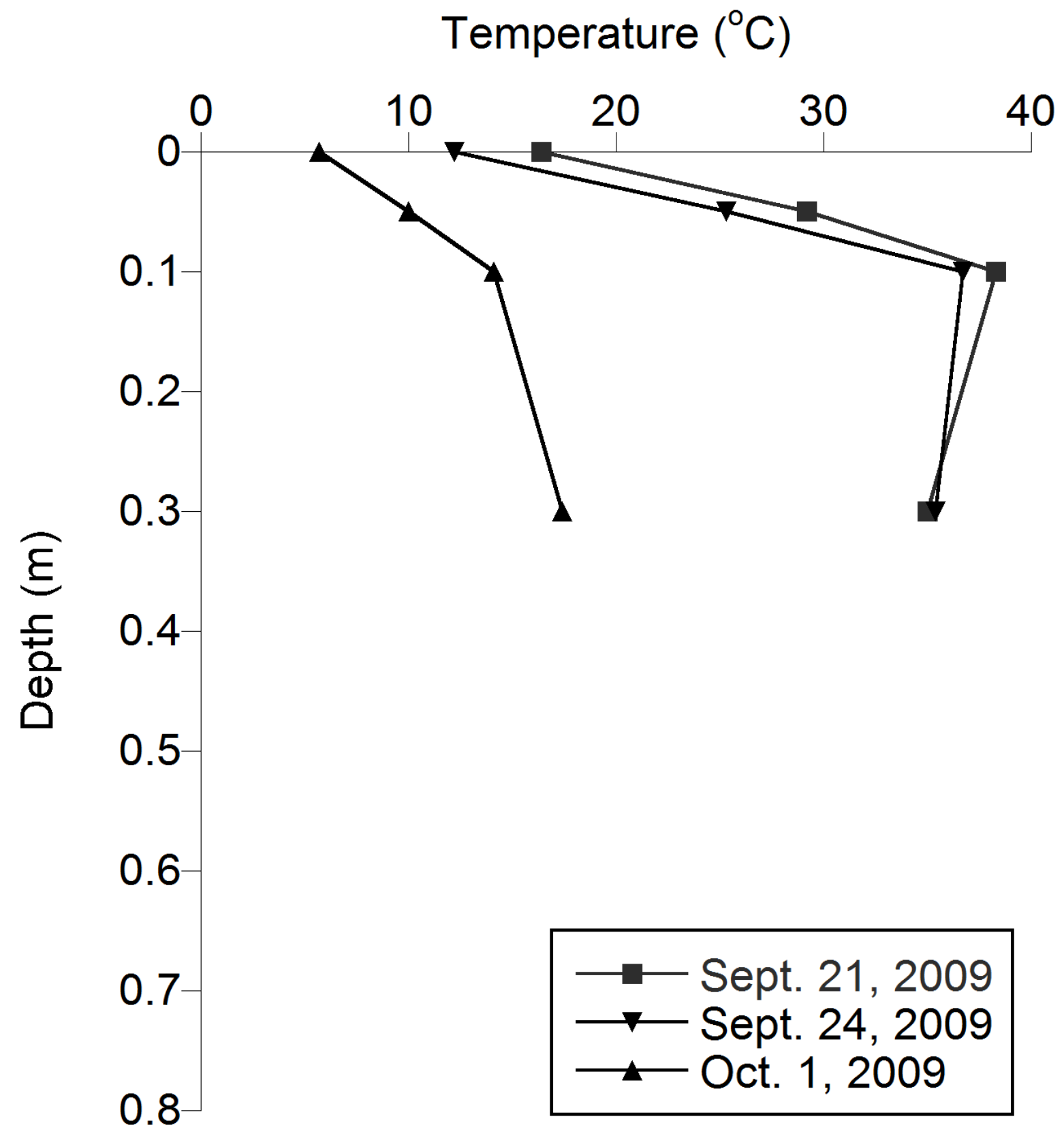

\section{PMOB-3B}

Figure 4b. 